
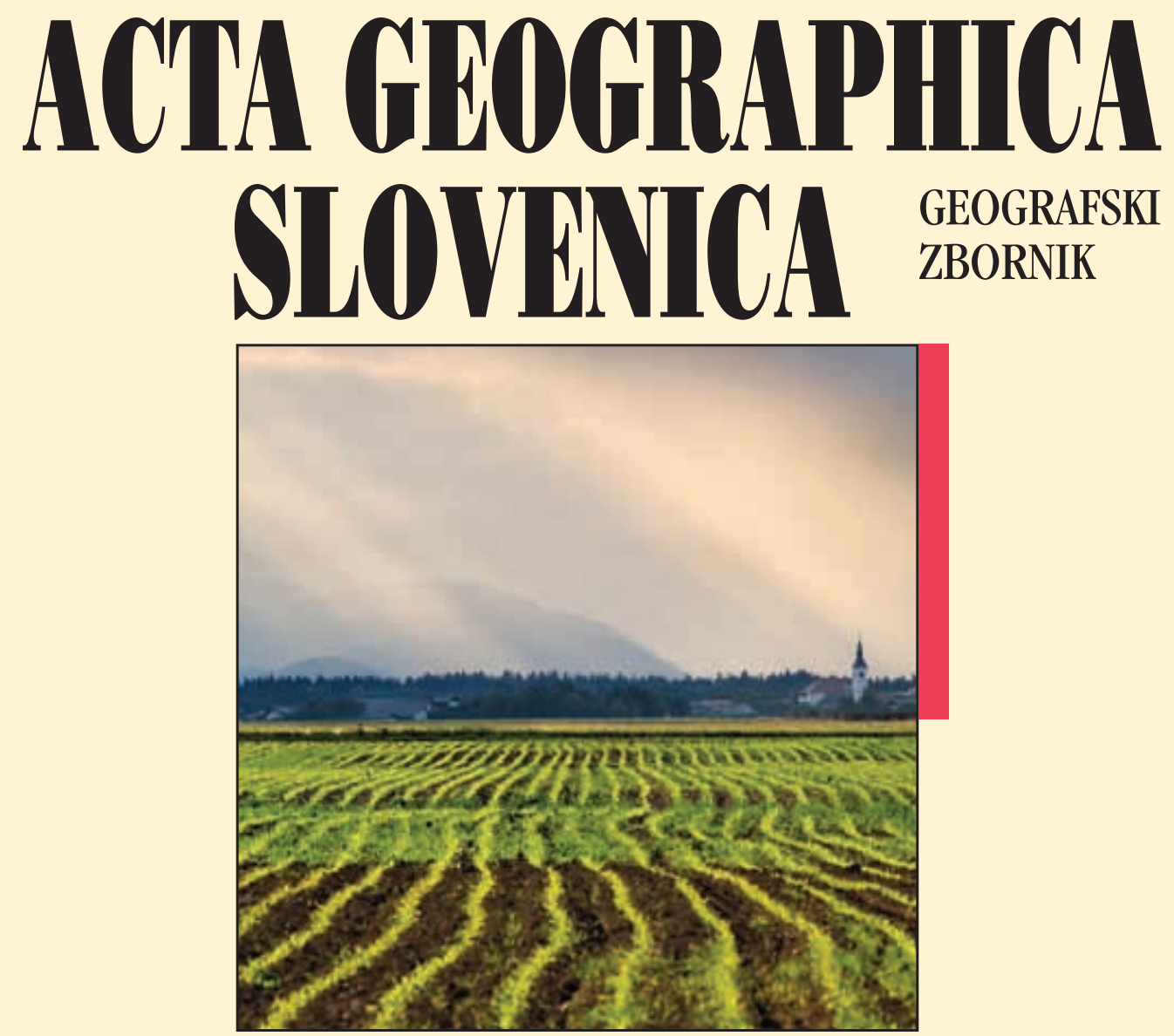

2018

58 


\section{ACTA GEOGRAPHICA SLOVENICA GEOGRAFSKI ZBORNIK \\ 58-1 • 2018}

\section{Contents}

Milivoj B. GAVRILOV, Slobodan B. MARKOVIĆ, Natalija JANC, Milena NIKOLIĆ, Aleksandar VALJAREVIĆ, Blaž KOMAC,

Matija ZORN, Milan PUNIŠIĆ†, Nikola BAČEVIĆ

Assessing average annual air temperature trends using the Mann-Kendall test in Kosovo

Liza STANČIČ, Blaž REPE

Post-fire succession: Selected examples from the Karst region, southwest Slovenia

Mirko GRČIĆ, Ljiljana GRČIĆ, Mikica SIBINOVIĆ

The geographical position of the town of Rasa based on Porphyrogenitus and medieval maps

Special issue - Agriculture in modern landscapes:

A factor hindering or facilitating development?

Nika RAZPOTNIK VISKOVIĆ, Blaž KOMAC

Agriculture in modern landscapes: A factor hindering or facilitating development?

Iwona MARKUSZEWSKA

Conflicts between legal policy and rural area management in Poland

Mojca FOŠKI

The (non)usefulness of the Register of Existing Agricultural and Forest

Land Use for monitoring the processes in urban areas

Maja POLENŠEK, Janez PIRNAT

Forest Patch Connectivity: The Case of the Kranj-Sora Basin, Slovenia

Karmen PAŽEK, Aleš IRGOLIČ, Jernej TURK, Andreja BOREC, Jernej PRIŠENK, Matej KOLENKO, Črtomir ROZMAN

Multi-criteria assessment of less favoured areas: A state level

Miomir M. JOVANOVIĆ, Miško M. MILANOVIĆ, Matija ZORN

The use of NDVI and CORINE Land Cover databases for forest management in Serbia

Darijo ILIĆ, Jože PANJAN

Nitrogen and Phosphorus Pollution in Goričko Nature Park

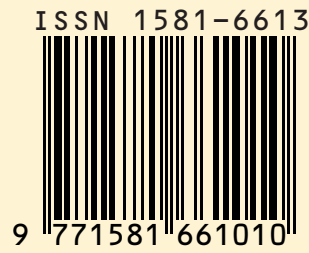




\section{ACTA GEOGRAPHICA SLOVENICA}

58-1

2018

ISSN: 1581-6613

COBISS: 124775936

UDC/UDK: 91

(C) Geografski inštitut Antona Melika ZRC SAZU 2018

International editorial board/mednarodni uredniški odbor: Michael Bründl (Switzerland), Rok Ciglič (Slovenia), Matej Gabrovec (Slovenia), Peter Jordan (Austria), Drago Kladnik (Slovenia), Blaž Komac (Slovenia), Andrej Kranjc (Slovenia), Dénes Lóczy (Hungary), Simon McCharty (United Kingdom), Slobodan Marković (Serbia), Milan Orožen Adamič (Slovenija), Drago Perko (Slovenia), Marjan Ravbar (Slovenia), Aleš Smrekar (Slovenia), Annett Steinführer (Germany), Mimi Urbanc (Slovenia), Matija Zorn (Slovenia).

Editor-in-Chief/glavni urednik: Blaž Komac; blaz@zrc-sazu.si

Executive editor/odgovorni urednik: Drago Perko; drago@zrc-sazu.si

Chief editor for physical geography/glavni urednik za fizično geografijo: Matija Zorn; matija.zorn@zrc-sazu.si Chief editor for human geography/glavna urednica za humano geografijo: Mimi Urbanc; mimi@zrc-sazu.si Chief editor for regional geography/glavni urednik za regionalno geografijo: Drago Kladnik; drago.kladnik@zrc-sazu.si Chief editor for spatial planning/glavni urednik za regionaln o planiranje: Janez Nared; janez.nared@zrc-sazu.si Chief editor for urban geography/glavni urednik za urbano geografijo: David Bole; david.bole@zrc-sazu.si Chief editor for geographic information systems/glavni urednik za geografske informacijske sisteme: Rok Ciglič; rok.ciglic@zrc-sazu.si

Chief editor for environmental protection/glavni urednik za varstvo okolja: Aleš Smrekar; ales.smrekar@zrc.sazu Editorial assistant/uredniški pomočnik: Matjaž Geršič; matjaz.gersic@zrc.sazu

Published by/izdajatelj: Geografski inštitut Antona Melika ZRC SAZU

Issued by/založnik: Založba ZRC

Co-issued by/sozaložnik: Slovenska akademija znanosti in umetnosti

Address/Naslov: Geografski inštitut Antona Melika ZRC SAZU, Gosposka ulica 13, SI - 1000 Ljubljana, Slovenija

The papers are available on-line/prispevki so dostopni na medmrežju:

http://ags.zrc-sazu.si (ISSN: 1581-8314)

Ordering/naročanje:

Založba ZRC

Novi trg 2, p. p. 306, SI - 1001 Ljubljana, Slovenija

Phone/telefon: +386 (0)1 4706464

Fax/faks: +386 (0)1 4257794

E-mail/e-pošta: zalozba@zrc-sazu.si

Annual subscription/letna naročnina: $20 €$ for individuals/za posameznike, $28 €$ for institutions/za ustanove. Single issue/cena posamezne številke: $12,50 €$ for individuals/za posameznike, $16 €$ for institutions/za ustanove.

Cartography/kartografija: Geografski inštitut Antona Melika ZRC SAZU

Translations/prevodi: DEKS, d.o.o.

DTP/prelom: SYNCOMP, d.o.o.

Printed by/tiskarna: Collegium Graphicum d. o. o.

Print run/naklada: 400 copies/izvodov

The journal is subsidized by the Slovenian Research Agency/revija izhaja s podporo Javne agencije za raziskovalno dejavnost Republike Slovenije.

The journal is indexed also in/revija je vključena tudi v: SCIE - Science citation index expanded, Scopus, JCR - Journal Citation Report/Science Edition, ERIH PLUS, GEOBASE Journals, Current geographical publications, EBSCOhost, Geoscience e-Journals, Georef, FRANCIS, SJR (SCImago Journal \& Country Rank), OCLC WorldCat, and Google scholar, CrossRef.

Front cover photography: Agriculture plays an important role in both protecting and developing farmland and is an important factor facilitating development of other sectors (photograph: Matej Lipar).

Fotografija na naslovnici: Kmetijstvo ima pomembno vlogo pri varovanju in razvoju kmetijskih zemljišč in je pomemben dejavnik tudi pri razvoju drugih sektorjev (fotografija: Matej Lipar). 


\section{THE GEOGRAPHICAL POSITION OF THE TOWN OF RASA BASED ON PORPHYROGENITUS AND MEDIEVAL MAPS}

Mirko Grčić, Ljiljana Grčić, Mikica Sibinović

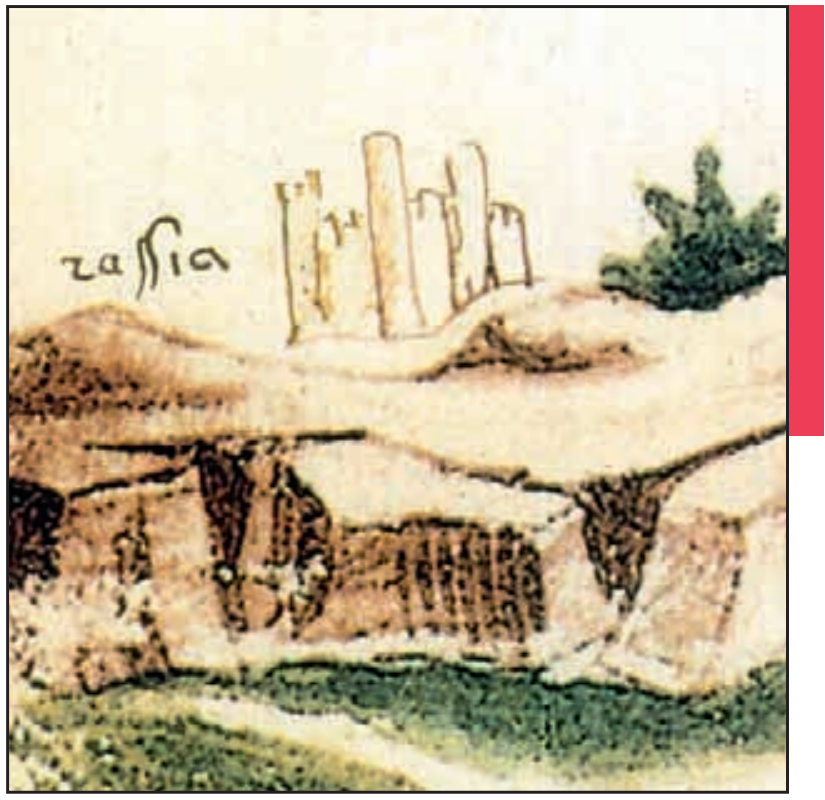

Detail from an anonymous military map of the Balkans from 1395 (Oračev 2005). 
DOI: https://doi.org/10.3986/AGS.1949

UDC: $911.375(497.11$ Rasa)(091)

912.43(497.11Rasa)(091)

COBISS: 1.01

\title{
The geographical position of the town of Rasa based on Porphyrogenitus and medieval maps
}

ABSTRACT: The town of Rasa was mentioned in the tenth-century work De administrando imperio by Constantine VII Porphyrogenitus. The significance of this town in the Middle Ages is indicated by the fact that this toponym appears on old maps created by the greatest European cartographers from the fifteenth to nineteenth centuries. Based on cartographic and historical geographical sources, this paper considers various perceptions and texts connecting the town of Rasa with today's town of Ražanj or with the medieval Serbian capital Ras. The subject treated is historical social geography. Five types of sources were used for the historical geography of the Balkans: old maps, chronicles, geographical nomenclature, archeological findings, and ethnographic findings. Based on written sources, geographical names, and geographical logic, the authors provide their own conclusions about the geographical position of the town of Rasa.

KEY WORDS: geography, old maps, geographical names, Rasa, Ras, Serbia

\section{Geografska lega mesta Rasa na podlagi Porfirogenetovih zapisov in srednjeveških zemljevidov}

POVZETEK: Mesto Rasa je prvič omenjeno v delu De administrando imperio, ki ga je v 10. stoletju napisal Konstantin VII. Porfirogenet. Na pomembnost mesta v srednjem veku kaže dejstvo, da se ta toponim pojavlja na zemljevidih, ki so jih med 15. in 19. stoletjem izdelali največji evropski kartografi. Na podlagi kartografskih in zgodovinskih geografskih virov so v članku obravnavana različna mnenja in besedila, ki Raso povezujejo z današnjim mestom Ražanj ali s srednjeveško srbsko prestolnico Ras. Glavna tema je zgodovinska družbena geografija. Za zgodovinsko geografsko obravnavo Balkana so avtorji uporabili pet vrst virov: stare zemljevide, kronike, geografska poimenovanja, arheološke najdbe in etnografske izsledke. Na podlagi pisnih virov, geografskih imen in geografske logike avtorji predstavijo lastne ugotovitve o geografski legi mesta Rasa.

KLJUČNE BESEDE: geografija, stari zemljevidi, geografska imena, Rasa, Ras, Srbija

\author{
Mirko Grčić, Ljiljana Grčić, Mikica Sibinović \\ University of Belgrade, Faculty of Geography, \\ mirko@gef.bg.ac.rs,mirko.grcic@yahoo.com, msibinovic@gef.bg.ac.rs
}

The paper was submitted for publication on April $5^{\text {th }}, 2016$.

Uredništvo je prejelo prispevek 5. aprila 2016. 


\section{Introduction}

Localization of geographic places mentioned in historical sources is an important goal of historical geographical research (Gašperič 2007; 2010; Kladnik and Pipan 2008; Vuolteenaho and Berg 2009; Vuolteenaho and Ainiala 2010; Douglas 2014; Fuchs 2015). In Constantine Porphyrogenitus' work De administrando imperio, chapter 32 contains the first mention of the town of Rasa. Namely, in the second Serbian-Bulgarian conflict in »the later period of the reign of Boris around $887 \mathrm{AD}$, « Boris had made peace with the Serbs,

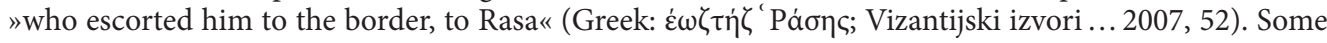
authors are uncertain whether this refers to Ras or Rasa. This study uses cartographic and historical sources to determine the location of Rasa, which Porphyrogenitus mentioned as a border town between Serbia and Bulgaria. This is an important question because in the toponymy of medieval Serbia there is the phonetically similar toponym Ras, which was the capital of the medieval Serbian state of Raška, which also has not been precisely located (Grčić and Grčić 2012; 2014).

\section{Theoretical framework}

The development of historical geography has raised awareness of four sources used in that discipline: 1) old chronicles, 2) ethnography, 3) geographic nomenclature, and 4) archaeology (Grčić and Grčić 2012; 2014). The Polish academy member Tadeusz Kotarbiński, who created "practicology« (or the »science of good work «), recommends that one not observe an object constantly through the same window, but look at it each time from another perspective (Trubačov 2006). This means that one should perceive the meaning of a certain toponym and its logical connection with the geographical area, ethnography, linguistics, written historical documents, cartographic sources, and archeological artifacts. The value of toponyms as a historical source lies in their relationship with the territory; that is, with the geographical map. Here arises a general question posed by Harley (1990): should a map be understood in a traditional way, as a reflection of the real world, or in the postmodern sense, as graphic language that needs to be decoded at the appropriate time and in a spatial context? In the second case, which is more appropriate for modern conceptions, the map should be considered within the context of historical facts, geographical principles, and maps of a given space and time. Without sufficient evidence, especially cartographic evidence, researchers can only point to some assumptions. For example, maps of the Roman provinces transmitted knowledge and expression of remembrance of political traditions more effectively than historical texts (Ćirković 1991).

\section{Methods}

Maps have long been very important to historical geography and the history of cartography, but they were rarely treated as a historical source in the reconstruction of the past (Gašperič 2007; 2010; Kladnik and Pipan 2008). In the development of cartography, there is a visible division between the »decorative« and "scientific " phases of mapping, but Harley (1990) recognized this division as a myth. Old maps have many pieces of information that are not precise and do not represent the only real picture of reality. Maps are socially constructed images of real space in social, political, and cultural contexts and a mirror of the skills and perceptions of the cartographer. This means that a particular map has to be returned to the past and situated in its proper period and place, or even culture (Fürst-Bjeliš and Zupanc 2007). When discussing a map as a text, Harley (1990) points out three aspects of the context: 1) the context of cartographer, 2) the contexts of other maps, and 3) the context of society. For this reason, it is necessary to use a comparative method and geographical logic in attempting to identify the Rasa mentioned by Porphyrogenitus in the tenth century. This toponym is studied by comparing selected maps from different times and cultures (see Table 1).

In addition to maps, we examined texts by Constantine Porphyrogenitus, the priest of Doclea (Duklja), and some Byzantine and church documents from Antiquity and the Middle Ages. We also considered the opinions of some prominent scholars about the genesis and geographic position of the toponyms Ras and Rasa. 
Mirko Grčić, Ljiljana Grčić, Mikica Sibinović, The geographical position of the town of Rasa based on Porphyrogenitus ...

Table 1: Toponyms on old maps denoting the position of Rasa near today's town of Ražanj.

\begin{tabular}{|c|c|c|}
\hline Cartographer & Map name, place, and year of publication & Toponym \\
\hline anonymous $^{*}$ & *Military map of the Balkans, 1395-1396 & Rossia \\
\hline JacoboCastaldo* & $\begin{array}{l}\text { Romanie (quae olim Thraciae dicta), Vicinuorumq(ue) regionum, uti Bulgariae, } \\
\text { Walachiae, Syrfiae etc descriptio, } 1584\end{array}$ & Rezuna \\
\hline Gerard Mercator* & Walachia. Servia. Bulgaria. Romania; Duisburg, 1589 & Resigne \\
\hline G. Cantelli***** & Map of Serbia (Rome, G. Rossi), 1689 & $\begin{array}{l}\text { Razena alt (ats), } \\
\text { Rasna }\end{array}$ \\
\hline Giacomo Cantelli da Vignola* & La Bulgaria e la Romania com Parte di Macedonia, Roma, 1689 & Rasna \\
\hline Pierre Mortier ${ }^{* * * *}$ & Carte Nouvelle de la Mer Mediterranee, Amsterdam, 1694 & Rasena \\
\hline Johann Georg Schreiber* & $\begin{array}{l}\text { Carte von Romanien mit dennes Dardanelen, Bulgarien und Servien. Leipzig, } \\
\text { end of the seventeenth century }\end{array}$ & Raszna \\
\hline MatthäusSeutter* & $\begin{array}{l}\text { Transylvaniæ, Moldaviæ, Walachiæ, Bulgariæ nova et accurata delineatio; eighteenth } \\
\text { century, Augsburg }\end{array}$ & Razena \\
\hline Guillaume Delisle*1 & $\begin{array}{l}\text { Imperii Orientalis et circumjacentium regionum sub Constantino Porphyrogenito } \\
\text { et ejuspraedecesforibusDescriptio, made after } 1718\end{array}$ & Rhazen \\
\hline Christoph Weigel* $^{*}$ & $\begin{array}{l}\text { Regiones Danubiæ, Pannoniæ, Dacia, Moesiæ cum Vicino Illyrico, studio Christoph; } \\
\text { Nuremberg, } 1719\end{array}$ & Razena \\
\hline Guillaume Delisle* & $\begin{array}{l}\text { Nova et accurata Regni Hungariæ Tabula, ad usum Serenissimi Burgundiæ Ducis, } \\
\text { first quarter of the eighteenth century }\end{array}$ & Razena \\
\hline MatthäusSeutter*** & Regnorum et Provinciarum Dalmatia, Croatia, Sclavonia, Bosnia, Servia, Istria et Reip, 1709 & Rasena \\
\hline anonymous* & $\begin{array}{l}\text { Parte della Transilvania, Parte della Banato, Parte della Servia, Parte della Bulgaria, Valachia } \\
\text { Imperiale, Valachia Thurca, 1717-1737 }\end{array}$ & Rasna \\
\hline Johann Matthias Hase ${ }^{*}$ & $\begin{array}{l}\text { Hungariæ, Propriæ, Croatie, Dalmatiæ, Bosniæ, Serviæ, Bulgariæ, Cumaniæ, Principatum: } \\
\text { Transsylvanniæ, Despotatus: Walachiæ, Moldaviæ; Nuremberg, } 1744\end{array}$ & Rasen, Rasna \\
\hline Antonio Zatta* & Turchiad'Europa. Divisa Nelle sue Provincie e Governi. Di nuova Proiezione; Venice, 1782 & Rozena \\
\hline F. Müller $* * * * *$ & Map of Serbia, Vienna, Artaria, 1788 & Razena, Ratzana \\
\hline
\end{tabular}

Sources: * Oračev 2005; *1 Ehrenberg, E. R. 2006 (National Geographic); ${ }^{* *}$ Nikolić 1983; ${ }^{* * *}$ Marković 2002; **** Schüler 2010; ***** Srejović 1991.

\section{Research findings}

\subsection{Historical geography of Rasa}

According to Castellan (1999) »between 867 and 874, the Serbs were under the control of the Byzantine church. The Serbs, who settled in the territory of Raška, between the Drina and Morava Rivers ... «. Near Varvarin (the village of Gornji Katun) was found one of the oldest monuments of Slavic literacy in Serbia and in the Balkans (from the ninth or tenth century): the Temnić inscription (Ivić 1986; Stojanović 1913). In a relatively small area between Stalać and Ražanj, on the slopes of the Mojsinje Mountains (Mojsinjske planine) and Poslon Mountains (Poslonske planine), there are a large number of churches and monasteries (including the ruins of seventy churches and hill forts); this area is known as Holy Mount Mojsinje (Mojsinjska Sveta gora). St. Roman's Monastery, which was founded in the second half of the ninth century, located seven kilometers south of the town of Ražanj (in the Niš District), also has significant cultural and historical value. The monastery was mentioned in a grant issued by Byzantine Emperor Basil II to the Archbishopric of Ohrid in 1020, in which it is recorded as Sfenteroman (Janićijević 1998; Živić 2006; Dumić, Đokić and Stević 2006). A charter issued by Byzantine Emperor Basil II to the Archbishopric of Ohrid in 1020, and confirmed by Emperor Michael Palaeologus in 1272, mentions among other things Raška or the Raska

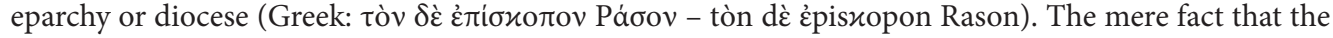
town was the seat of a bishop indicates that it was a remarkable town in a good transport position. Some Bulgarian and Russian authors from the second half of the nineteenth century thought that this referred 
to Ras near today's town of Novi Pazar on the Raška River, which flows into the Ibar (Golubinskij 1871; Drinov 1971).

Based on the Escorial Taktikon - a list of offices that arose from the need to administer the newly conquered provinces of Bulgaria at the time of John Tzimiskes (969-975) in the official administration of Byzantium Stanković (2002) points out that to the west there was an administrative unit with its center in Ras. The existence of this administrative unit remained recorded only thanks to a seal by John, the katepan of Ras (Nesbit and Oikonomides 1991). In Greek, a katepanat was a large territory in a border zone that included several themes (administrative units) in which civilian and military power was exercised by a katepan. The katepan (or $d u x$ ) was a title carried during the Roman and Byzantine period by military commanders in a province (Touati 2007). The theme of Morava was also established; this was led by Adralest Diogenes and was located near the confluence of the Morava and Danube Rivers, at the site of the ancient fort called Horreum Margi (Stanković 2002; Pirivatrić 1997). According to Živković (2007), Byzantine seals (Protospatharios John, katepan of Ras, as well as the seal of Adralesta Diogenes, a protospatharios and strategist of Morava), are the most reliable indicator that Byzantine reign was established in this border area.

The town of Rasa, mentioned at the end of the ninth century, is identified by some authors with Ras, the capital of Stefan Nemanja's Serbia in the second half of the twelfth century (Novakovic 1877). Only at the end of the nineteenth century did Ras (i.e., Apostles Peter and Paul Church, which was known to be located in Ras) appear on maps drawn near Novi Pazar (the Austrian military map from 1900). In 1859, the Russian historian Alexander Hilferding, on his way through Old Serbia, thought that he recognized the town of Ras about seven kilometers west of Novi Pazar, in the ruins known as Gradina near Pazarište, near where the Sebečevska River empties into the Raška River. »I have no doubt that these ruins are in fact the old town of Ras, about which a lot was said in ancient Serbian history" (Hilferding $1868 \mathrm{cv}$ : Hilferding 1972, 134). According to Ćirković, »although the arguments were insufficient, many scholars (Konstantin Jireček, Stojan Novaković, Jovan Cvijić) agreed with Hilferding's opinion, and so over time identifying Ras with one of the many fort ruins was generally accepted as unproblematic (Ćirković 1997, 425). It is usually assumed that Ras was several kilometers from Novi Pazar, at a place called Pazarište or Eski Pazar (i.e., 'old Pazar'). »Here, however, are no ruins " (Dinić 1978, 80). Kalić raises the possibility that the place called Race referred to Arsa (Kalić 1988). According to Ćirković, »It is more likely that this Rasa in the country of Michael or

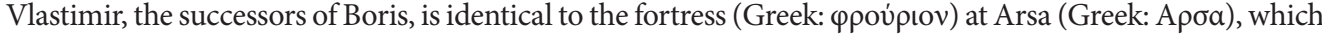
according to the narratives of Procopius was rebuilt by Emperor Justinian in the province of Dardania « (Ćirković 1997, 424). However, the attention of European medieval cartographers was directed toward a town with a similar name, which was located near the present town of Ražanj.

\subsection{The toponym Rasa on old geographic maps}

The old Roman military road (Latin: Via Militaris) known as the Moravian road led through the Roman town of Arsena, where Justinian built a fortress (Jireček 1959). Along the route of the public road (Latin: Via Publica), in the village of Novi Bračin north of the town of Ražanj, there was an ancient settlement called Præsidium Dasmini. The ancient settlements of Præsidium Dasmini and Præsidium Pompeiare shown on the Tabula Peutingeriana, a Roman itinerary map (SegmentumVII; Figure 2). In the centre of the northern part of the Aleksinac Basin was Mutatio Cametas, today's town of Ražanj. Felix Kanitz mentioned this as an important point on the route of the ancient Moravian road (Rašković 2002).

Separating the last syllable from the word Arsena yields the name Arsa. It can be assumed that the name Rasa is a translation of the Greek word Arsa; today's Raša River in the Istria Peninsula in northwest Croatia was called Arsa in Roman times. The Slavic name Rasena or Rasna undoubtedly inherited the ancient name of the town, Arsena. It seems, however, that the ancient toponym Arsena signified some kind of art or skill. The etymology of the word rasa can be connected with a place of ecclesiastical authority. According to the Bulgarian terminology dictionary (Bălgarski tolkovski rechnik 2013), raso refers to the black, wide, long upper garments of an Orthodox priest. In Greek, rason designates the large wide-sleeved clothing worn by priests and Byzantine church monks (Touati 2007). According to the Klaić dictionary (1970), ras means 'prince'. Thus, the name Raška could mean 'principality'. Mihailo Dinić ruled out the possibility that the name of the mediaeval state of Raška came from the name of the town of Ras (Dinić 1966).

The place called Rasa was not precisely localized, its name is only known in the form in which it appears in Porphyrogenitus' work (Greek: Páōৎ). Porphyrogenitus reported that Rasa was a border crossing between 
Serbia and Bulgaria. The map by the prominent French cartographer Guillaume Delisle, »Eastern Empire and Neighbouring Regions According to Constantine Porphyrogenitus «, shows Rasa (German: Ratzen) on the Serbian-Bulgarian border, but on the Bulgarian side (Grčić and Grčić 2012, 8). According to Dinić (1966), it should not be excluded that Porphyrogenitus' Rasa belonged to Bulgaria. In any case, it is a border fortress between the two countries (Grčić and Grčić 2014).

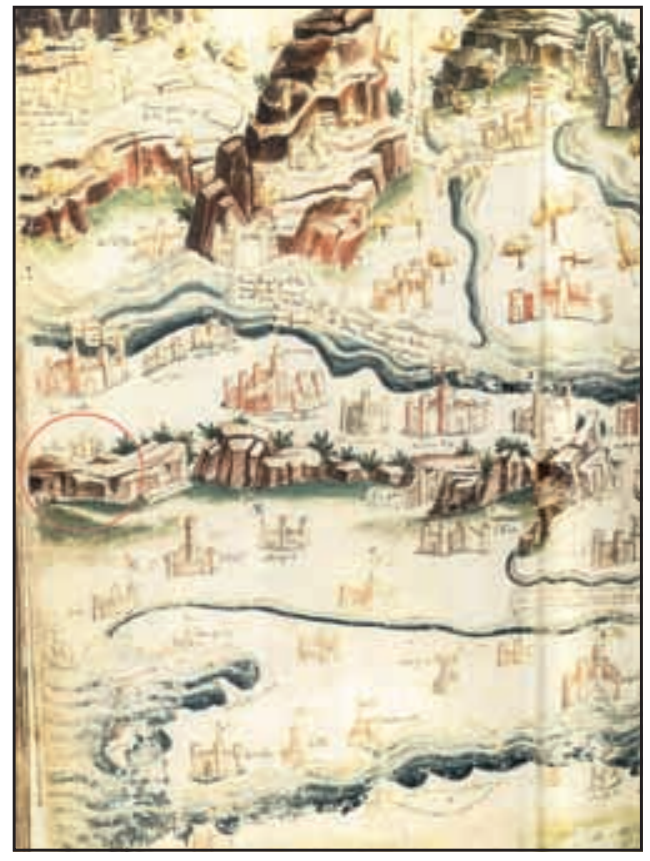

Figure 1: Part of the military map of the Balkans (Oračev 2005).

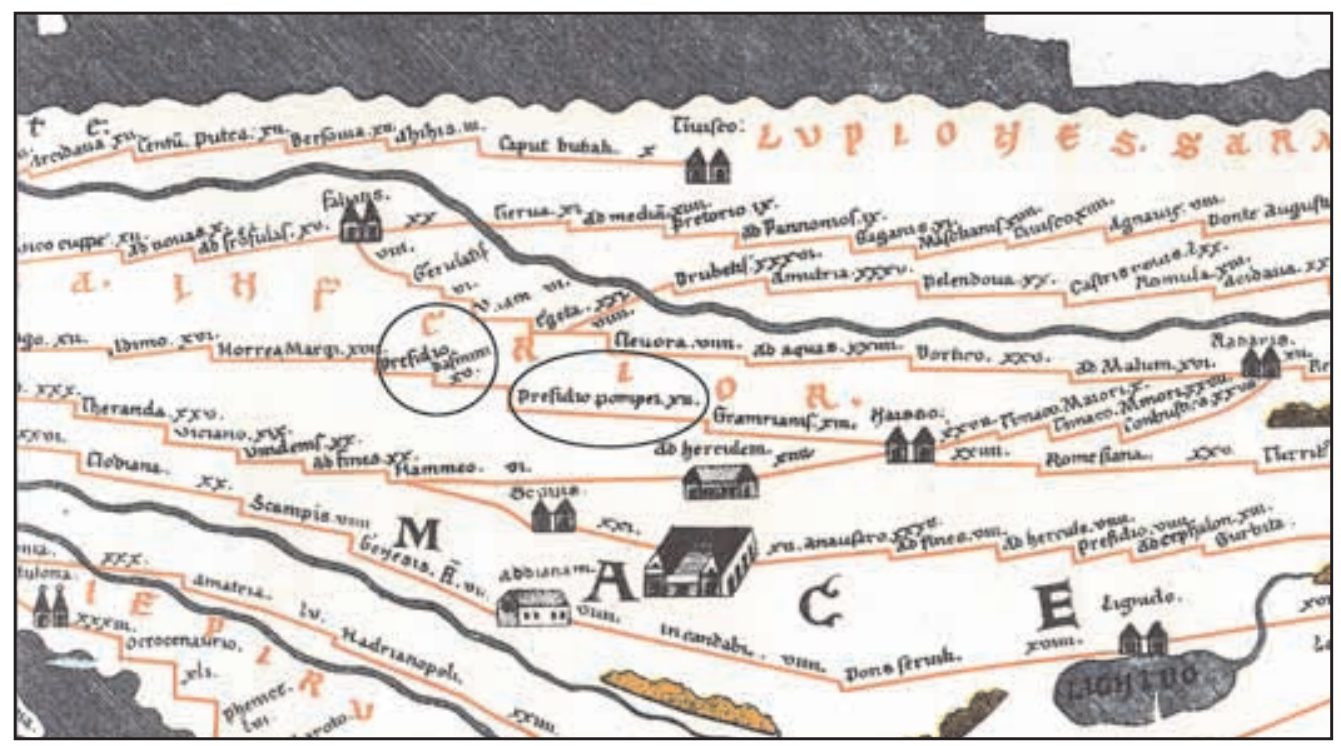

Figure 2: Fragment of the Tabula Peutingeriana (Segment 7; Sectors 3, 4) (Weltkarte des Castorius, genannt die Peutingersche Tafel 1888). 


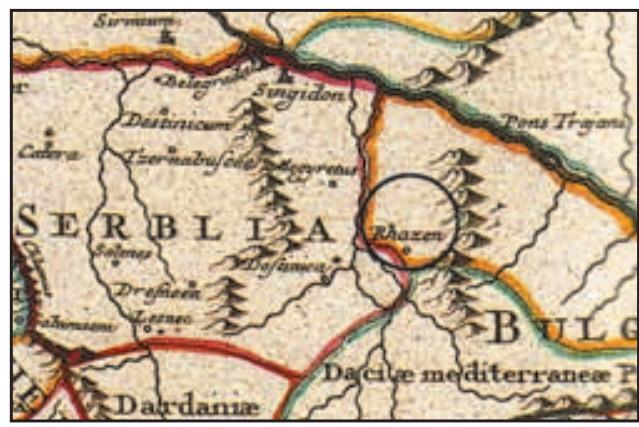

3.1. Rhazen (Guillaume Delisle, Eastern Empire and surrounding regions according to Constantine Porphyrogenitus, 1718).

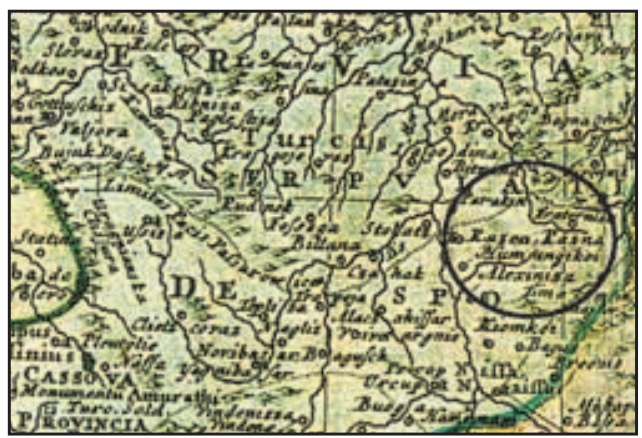

3.3. Rasen, Rasna (Johann Matthias Haas, Map of Hungary and part of Croatia, Dalmatia, Bosnia, Serbia, Bulgaria, 1744).

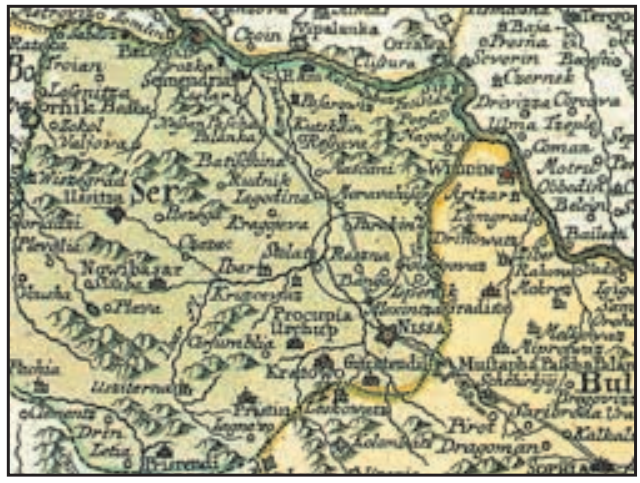

3.5. Raszna (Johann Schreiber, Map of Romania with the Dardanelles, Bulgaria and Serbia, end of the seventeenth century).

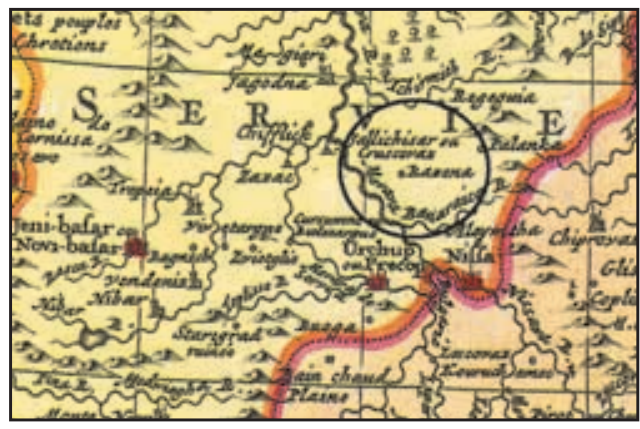

3.2. Rasena (Guillaume Delisle, Map of the Hungarian Kingdom, first quarter of the eighteenth century).

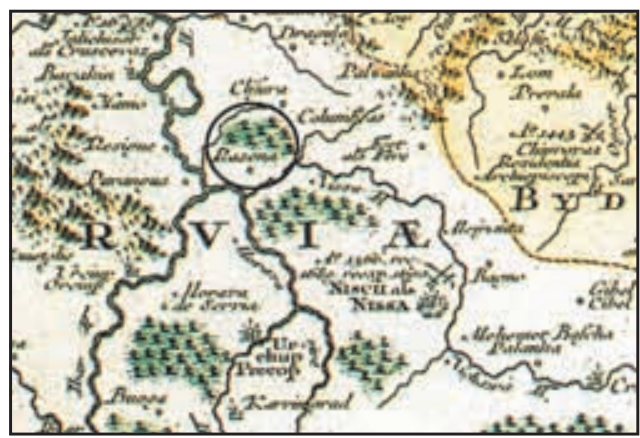

3.4. Razena (Mattheus Seutter, Map of Transylvania, Moldavia, Walachia, Bulgaria, beginning of the eighteenth century).

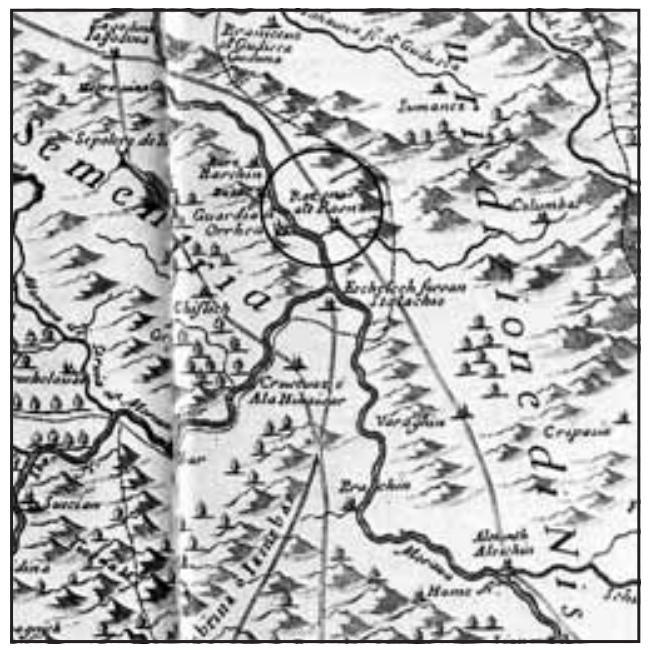

3.6. Razena alt (ats), Rasna (Giacomo Cantelli da Vignola, Map of Serbia, 1689). 
For this discussion, the military map (Figure 1) is of particular importance. It is the work of an anonymous author and is kept by the National Library in Paris in the Pauli Sanctini manuscript (Codex Latinus Parisinus, register number 7239). This map shows a large part of the Balkan Peninsula, from Belgrade to Istanbul. Estimated on the basis of the Ottoman flags, the possible time of creation of this map is 1395 or 1396 (Beševliev 1963; Oračev 2005). Fortified towns are represented in the form of vignettes. North of the city of Niš is shown a fortified town called Rossia (or Rassia; Figure 1). On this map, the name Rossia is printed on the approximate territory of today's town of Ražanj, as well as on many other old maps (Table 1). On this map, the town of Rasa is shown as a border town in Serbia, and on the other side of the gorge is written Bulgaria. In the fourteenth century in a nearby gorge, between Mounts Ozren and Rtanj, was the Bulgarian-Serbian border (Jireček 1959). The map is striking with its cartographic projection because it reveals some parallels with the Roman itinerary map Tabula Peutingeriana (Figure 2).

There are almost no old maps showing the Morava River from the end of the fourteenth century until the twentieth century that do not show a place called Rasen, Rasena, Razena, Rozena, Rasna, Raszna, Resigne, Rhazen, and finally Ražanj (Table 1 and Figure 3). Medieval maps are characterized by the similarity of the location of this place in regard to the relief and river flows (Figure 3). Some data from this and other old medieval maps can possibly provide the key for understanding the localization of the ninth-century border town of Rasa.

\section{Conclusion}

The historiographical text by Byzantine Emperor Constantine VII Porphyrogenitus, De administrando imperio, provides a testimony about the geography of settlements in the Balkan Peninsula in the second half of the ninth century and first half of the tenth century. This article addresses the border town of Rasa. Many scholars (Dinić, Ćirković, Kalić) have doubted the traditional theory of the precise location of the place. The issue may be resolved by old maps. Particular support in this regard may be maps created by prominent cartographers from the end of the fourteenth century to the end of the eighteenth century. This paper points to Ražanj, which could be the border town of Rasa (Rasen), which was mentioned by Porphyrogenitus as a place near the Serbian-Bulgarian border.

ACKNOWLEDGEMENT: This paper is the result of research within project no. 176017 funded by the Ministry of Education and Science of the Republic of Serbia.

\section{References}

Bălgarski tolkovski rechnik, 2013. Nauka i izkustvo. Sofija.

Beševliev, V. 1963: Eine Militärkarte der Balkanhalbinsel aus den letzen Jahren des 14. Jahrhunderts. Balkansko ezikoznanie 7-2.

Castellan, G. 1999: Histoire des Balkans. Paris.

Ćirković, S. 1991: Svedočenje karte. Srbija i susedne zemlje na starim geografskim kartama. Beograd.

Ćirković, S. 1997: Rabotnici, vojnici, duhovnici: Društva srednjovekovnog Balkana. Beograd.

Delisle, G. 1718: Eastern Empire and surrounding regions according to Constantine Porphyrogenitus. Paris.

Dinić, M. 1966: O nazivima srednjovenkovne srpske države. Prilozi za književnost, jezik, istoriju i folklor 32-1.

Dinić, M. 1978: Zapadna Srbija u srednjem veku. Srpske zemlje u srednjem veku. Beograd.

Douglas, B. 2014: Naming places: voyagers, toponyms, and local presence in the fifth part of the world, 1500-1700. Journal of Historical Geography 45. DOI: http://dx.doi.org/10.1016/j.jhg.2014.03.004

Drinov, M. 1971: Izbranisačinenija I. Trudove po balgarska i slavjanska istorija. Sofija.

Dumić, O., Đokić, N., Stević, M. 2006: Manastir sv. Roman. Kruševac.

Ehrenberg, E. R. 2006: National geographic mapping the world: an illustrated history of cartography. Washington D.C.

Fuchs, S. 2015: History and heritage of two Midwest towns: a toponymic-material approach. Journal of Historical Geography 48. DOI: http://dx.doi.org/10.1016/j.jhg.2015.01.003 
Fürst-Bjeliš, B., Zupanc, I. 2007: Images of the Croatian borderlands: selected examples of early modern cartography. Hrvatski geografski glasnik 69-1.

Gašperič, P. 2007: Cartographic images of Slovenia through time. Acta geographica Slovenica 47-2. DOI: http://dx.doi.org/10.3986/AGS47205

Gašperič, P. 2010: The 1812 map of the Illyrian provinces by Gaetan Palma. Acta geographica Slovenica 50-2. DOI: http://dx.doi.org/10.3986/AGS50205

Golubinskij, E. 1871: Kratkij očerk pravoslavnih cerkvej: bolgarskoj, serbskoj i rominskoj. Moskva.

Grčić, M., Grčić, L. 2012: Prvi naseljeni gradovi pokrštene Srbije X. veka prema Konstantinu Porfirogenitu na karti Gijom de Lila. Glasnik Srpskog geografskog društva 92-2. DOI: http://dx.doi.org/10.2298/ GSGD1202001G

Grčić, M., Grčić, L. 2014: Zemlje i gradovi Zapadnog Balkana u X. veku prema delu Konstantina Porfirogenita prikazani na karti Gijom de Lila početkom 18. veka. Glasnik Geografskog društva Republike Srpske 18-1.

Harley, J. B. 1990: Introduction: text and contexts in the interpretation of early maps. Chicago.

Haas, J. M. 1744: Map of Hungary and part of Croatia, Dalmatia, Bosnia, Serbia, Bulgaria. Halle.

Hilferding, A. 1972: Putovanje po Hercegovini, Bosni i Staroj Srbiji. Sarajevo.

Hilferding, F. A. 1868: Sobranie sočinenija I. Sankt Peterburg.

Ivić, P. 1986: Srpski narod i njegov jezik. Beograd.

Janićijević, J. 1998: Kulturna riznica Srbije. Beograd.

Jireček, K. 1959: Trgovački putevi i rudnici Srbije i Bosne u srednjem veku. Zbornik Konstantina Jirečeka 1. Beograd.

Kalić J. 1988: La région de Ras à l'epoque byzantine. Geographie historique du monde méditerranéen Byzantina Sorbonensia 7.

Kladnik, D., Pipan, P. 2008: Bay of Piran or Bay of Savudrija? An example of problematic treatment of geographical names. Acta geographica Slovenica 48-1. DOI: http://dx.doi.org/10.3986/AGS48103

Klaić, Ž. 1970: Veliki rječnik stranih riječi. Zagreb.

Marković, M. 2002: Slavonija - Povijest naselja i stanovništva. Zagreb.

Nesbit, J., Oikonomides, N. 1991: Catalogue of Byzantine seals of Dumbarton Oaks and in the Fogg Museum of Art 1. Washington D.C.

Nikolić, M. 1983: Karta Balkanskog poluostrva iz prve polovine XV. veka. Istorijski časopis 29-30.

Novaković, S. 1877: Zemljište radnje Nemanjine, Istorijsko-geografska studija. Beograd.

Oračev, A. 2005: Balgarija v evropejskite kartografski predstavi do XIX. vek. Sofija.

Pirivatrić, V. 1997: Vizantijska tema Morava i »Moravije« Konstantina Porfirogenita. Zbornik radova Vizantološkog instituta 36.

Rašković, D. 2002: Ranovizantijski arheološki lokaliteti i komunikacije u širem Kruševačkom okružju. Treća jugoslovenska konferencija Vizantologa. Beograd, Kruševac.

Schüler, C. J. 2010: Maailmaa Kartoittamassa. Paris.

Srejović, D. 1991: Srbija i susedne zemlje na starim geografskim kartama. Katalog izložbe SANU. Beograd.

Stanković, V. 2002: Karakter vizantijske granice na Balkanu u IX. i X. veku. Treća jugoslovenska konferencija Vizantologa. Beograd, Kruševac.

Stojanović, L. 1913: Temnićki natpis. Južnoslovenski filolog 5.

Touati, F. O. 2007: Vocabulaire historique du Moyen Age: Occident, Byzantin, Islam. Paris.

Trubačov, O. 2006: Etnogeneza i kultura drevnih Slovena. Beograd.

Vignola, G. C. 1689: Map of Serbia. Rome.

Vizantijski izvori za istoriju naroda Jugoslavije II. Vizantološki institut SANU. Beograd, 2007.

Vuolteenaho, J., Ainiala, T. 2010: Naming and making places: Excavating the connection between nation-building and toponymic research. Language and the Moulding of Space. Magdeburg.

Vuolteenaho, J., Berg, L. D. 2009: Toward critical toponymies. Critical toponymies: the contested politics of place naming. Burlington.

Weltkarte des Castorius, genannt die Peutingersche Tafel 1888, Berlin.

Živić, M. 2006: Isceliteljska moć sv. Romana. Acta medica Medianae 45-4.

Živković, T. 2007: Južni Sloveni pod vizantijskom vlašću 600-1025. Beograd. 